\title{
Introduction: Angels and Demons
}

\author{
Andrew King
}

This special issue of Critical Survey stems from a conference at Canterbury Christ Church University in June 2010 that was intended to explore continuities and ruptures in the representation and deployment of angels and demons and related binaries, be they in nineteenth-century print media or seventeenth-century Protestant texts, twenty-first century bestsellers or company PR strategies. From the first it was decided that discussion should not be limited to actual angels and demons, but the more general binaries of good and evil, lucid self and obscure Other. Considerations of the generic processes of demonisation and its opposite were also welcome, as were attempts to think outside such binaries (insofar as such is possible). Was it the case that the undoing of binaries, vital to Cixous' feminist enterprise and deconstruction generally, was salient today for the various politics of gender, sexuality, 'race', class, disability, and place, or had such deconstruction been so co-opted by conservative commercial culture (as was always possible according to Christopher Norris) ${ }^{1}$ that alternative strategies were necessary? All these ways of thinking about angels and demons are represented in the essays that follow.

Why this topic now? Even if barely visible to those of us in the academy with pretentions to critical analysis and sceptical distance, the angel and demon binary still inhabits huge swathes of cultural space in the technophilic twenty-first century. The demonisation of Saddam Hussein and Osama bin Laden over the last two decades is well documented, ${ }^{2}$ but that mythologising tactic is not confined to war or even to its extension, politics. Representations of angels and demons - especially demons - are ubiquitous. As I write this Introduction in the late spring of 2011, the New York pop star, Lady Gaga, playing Mary Magdalene in her pop video of Judas, is singing that 'Jesus is [her] virtue, / Judas is the demon [she] cling[s] to'. Touched by an Angel, a popular nine-season CBS fiction series 
(1994-2003) that revolves around the trials of a trainee angel in delivering godly messages to characters at cross-roads in their lives, is being broadcast on UK television. ${ }^{3}$ And of course, angels and demons figure protagonist and antagonist and their circles in Dan Brown's enormously successful novel (2000) and the film (2009) of that name. Gaga's typically brilliant commercial ambivalence notwithstanding, in all the above the binary of good angel and evil demon remains simple and unreversed. But since Milton the devil has often been more attractive, and, at least since the nineteenth century, we have regarded angels as suspect: for Virginia Woolf it was a 'guardian angel' in the form of a beadle who blocked her from seeing the manuscript of Lycidas in an Oxbridge college, and, more famously, it was the 'angel of the house' that was the most repressive of all ideological constructions for women. ${ }^{4}$ While we had seen what was to all intents and purposes the Devil in traditional horned form in a 2007 episode of the mass-market BBC series Dr Who ('The Satan Pit'), much scarier were the murderous 'weeping Angels', whose shape recalls Victorian funerary sculpture ('Blink', 2007, 'The Time of Angels', 'Flesh and Stone', 2010). The more culturally élite and liberal audience that appreciated the $2003 \mathrm{HBO}$ mini-series Angels in America, based on Tony Kushner's epic plays from 1990-95, likewise saw angels as fundamentally hostile. There they are not messengers of the good news of future salvation but an initially terrifying and in the end helpless force for reactionary conservatism that is eventually rejected in favour of community and change. Despite Touched by an Angel, it seems we prefer our angels as either demons or, at least, as ambivalent as in the Buffy spin-off Angel (1999-2004). The present collection confirms by their omission that uncomplicated angels tend to be uninteresting: only when they become mixed beings do we have much to say about them. If we have to have an angel, we prefer it as really a 'devil in the coat of an angel' as James VI's court minister described one of his master's political enemies (quoted in Stilma below).

Just this year, Fred Parker explored the intersection of aesthetics and ethics through the figure of the literary devil in Blake, Byron, and Mann. ${ }^{5}$ His first example of a manifestation of the devil is, however, Mammon, the personification of greed and the unjust accumulation of wealth. Indeed, what unites several of the articles in this collection is the relationship of good and evil to economic systems, be that relationship rendered obvious or not. It is most apparent in Ágnes 
Gulyás's data-rich account of the changing role that the notion of corporate social responsibility (CSR) has had in the self-presentation of transnational media corporations as ethical beings, guardians of the future, bearers of good tidings - as indeed angels. Inheritors of the hermeneutics of suspicion, we cannot but ask, along with Bourdieu, whether the reports of CSR that Gulyás describes are but a cynical disguise of the demon in angelic robes, 'a return to forms of symbolic violence again based on dissimulation of the mechanisms of reproduction through the conversion of economic into symbolic capital' ${ }^{6}$

As Deborah Mutch explains, some of the most profitable products of transnational media corporations seem to promote a socially responsible agenda. Both Stephenie Meyers' Twilight and Charlaine Harris's Sookie Stackhouse vampire series argue for an integrated society, where 'racial' difference can be accommodated without losing its particularity. Certainly no longer human, the threatening Other for the liberal capitalist West is now not even the nonhuman vampire or werewolf. Rather that role is assigned to quasigovernmental organisations that interfere with private lives. The narratives that Mutch discusses instead become justifications for American political and economic Individualism. Furthermore, the connection established between vampirism and capital accumulation - an 'allegorical' condemnation of unjust profiteering that goes back in English at least to the Gentleman's Magazine of May $1732^{7}$ - is given a positive spin by Harris. One inevitably wonders therefore if this happy deconstruction of the human and non-human binary is to be taken straight or whether it is yet another version of the 'dissimulation of the mechanisms of reproduction'. It may be that if the social impact of media companies is not a focus in their CSR reporting (as Gulyás records), then perhaps some of their products do it for them, providing an allegorical redefinition of their activities - an elegant co-optation by the commercial of a potentially radical enterprise.

One wonders too at the relation of the 'New Woman's' uncertain status in Jerome K. Jerome's publications to the economic necessities of the media industry of his time. Carolyn Oulton details the fuzzy oscillations of Jerome's definition of the bete noire of so many reactionary publications of the late-nineteenth century, and suggests that he was 'banishing the beast' by trying to 'write the New Woman out of existence'. Jerome had begun To-day, a $2 \mathrm{~d}$ weekly 'magazine-journal', shortly before the media showdown between 
Sarah Grand and Ouida made the New Woman one of the most demonised constructions of the mid-1890s. In a series of editorials and commissioned articles between 1894 and 1897 Jerome explored the range of meanings accruing around this figure, attacking both the New Woman herself and the reactionary male attitudes he saw as partly responsible for her rebellion. But was Jerome concerned less with gender politics than commerce, perhaps trying out different versions of the 'New Woman' for different readerships? To-day, with its notable coterie of contributors (including Kipling, Stevenson, Le Gallienne, Harte, Beardsley, Phil May) was commercially very successful until 1894 when the city editor foolishly attacked an investor who promptly sued. ${ }^{8}$ In his later fiction Jerome continued to explore the problem of gender relations, again, it seems, with an eye on the market. In Tommy \& Co. (1904) the eponymous protagonist is an updated and media savvy descendent of the tomboy heroine of one of the most commercially successful novels of the entire nineteenth century, E.D.E.N. Southworth's The Hidden Hand (1854). Amongst Jerome's last novels, All Roads Lead to Calvary (1919) responds to how the recent war had further problematised the question of women's proper role. While the heroine insists that women were made to be the responsible helpmeets of men rather than their competitors, the unhappy marriage of her mother, a former actress, provides a powerful subtext to this surface resolution. As has been known for a long time, oscillations and ambiguities such as these are characteristic of texts that aim for wide commercial success: to come out too definitely on one side would be to exclude a potentially large segment of the market. In this understanding, gender differences might comprise only pieces on a media market chess board and as such capable of constant movement. The real game is between the binary of profit and loss.

For Elizabeth Hoult, following Cixous, such a hypocritical game would, however, ultimately be founded on gender. It would be the typical disavowal of a masculine economy that seeks to expel or destroy in the interest of 'return' as profit. In her blending of two disciplines (education and literature) and two times (Shakespearean and now), Hoult polemically offers an alternative economy, outside the controlling masculine that seeks to keep things and people in their places for exploitation. She reads a play, Shakespeare's $A$ Winter's Tale, as capable of teaching us about a form of teaching that no education reliant for its operation on league tables can ever recognise. The gift of pedagogic love is not based on profit or loss and even 
breaks down the binary of student and teacher. Instead it encourages process, movement, relationality, play. It is a non-hierarchical, permissive, paratactic connection that allows 'resilience' to thrive. Neither angel nor demon, such an alternative 'feminine' economy announces salvation through inclusivity and conjunction. While perhaps superficially similar to the Harris and Meyer in its calls for inclusivity, what Hoult offers is local and, crucially, unmediated. And unlike their texts, she promotes a practice that refuses imbrication in transnational or indeed in any media corporations in favour of personal, direct, transactions.

While in almost all texts today angels and demons are allegories that link the unreal and the real, fiction with the economies and experiences of daily life, for the early seventeenth century that two of the articles in this number explore, allegory was still understood in its mediaeval sense of linking levels of reality. This is evident from Michelle Brock's discussion of how important the devil was in the self-writings of three Scottish Reform Protestants. If demonic belief in Scotland has hitherto primarily been addressed in the context of the witch trials where the devil appeared as an external figure that convinced morally weak people (mostly women) to renounce their baptisms, enter into a demonic pact, and commit atrocious crimes, diaries and letters demonstrate how encountering the devil could be less spectacular while still a very powerful personal experience. These were not abstract encounters with a figure symbolising something other than itself (greed, capitalism, modernity, gender reconfiguration) but with something real that generated intense physical and psychological effects.

Confirming that the devil was an entity with whom one entered into combat real, for all that it was psychological, Astrid Stilma goes on to show the semantic richness that could be generated by the tropological (moralising) tradition of biblical exegesis (such as we see in renaissance iconography where angels are only ever representations of ideal reactions to events - rejoicing at the birth of Christ, lamenting at the Deposition). Such interpretation of devils and angels opened up the avowedly fictional supernatural figures that appeared on stage to signposting some of the major religio-political debates of the period, such as Divine Right kingship, the (il)legitimacy of rebellion, and the ever-fraught issue of religious difference. Although invoking angels or demons can be a rather blunt instrument to manipulate public opinion - there is, for instance, as little subtlety in the devil-dealing 
Popes of some of the ultra-Protestant dramas that were written in the wake of the Gunpowder Plot as there was in the tabloid treatment of Saddam Hussein - such characters were also employed by some playwrights to question more ambiguously the extent to which human politics could ever claim interaction with supernatural forces, for all that such figures were believed to take physical form and to direct historical events. What unites too the Stilma and the Brock is the continuing vitality of an Old Testament version of the devil where he is part of God's plan. In the end, there is only God; the devil is less a real adversary in a binary opposition than a servant, another form of angel that confirms, if indirectly, the omnipotence of the One. ${ }^{11}$ As the Presbyterian minister John Welwood wrote in a letter in 1676, '[God] sits at the helmn of this world, and all creatures are but carrying on his designs. Devills and wicked men are as bussy doing his work as saints and angels...' (quoted in Brock below).

This returns us to the initial question about the political value of undoing the binaries of good and evil. As we have seen, popular culture today seems to embrace both their construction (inverted though they may be so that devils become sympathetic and angels antagonistic) and deconstruction. In either case the vitality of angels and demons is ensured. However, the collection also points to a rupture in the use of the binary - and to a question that contributors prefer to leave in abeyance. That good and evil are no longer epiphenomena of the divine as in the seventeenth century is obvious. There lies the rupture. Literary historians may point to Milton's treatment of Satan as key to this epistemic shift; but perhaps there is a less personal contributory cause, manifested over 1719-20 in the South Sea Bubble and the Mississippi Scheme of that 'fils aîné de Satan', John Law. ${ }^{9}$ For how much are the now happily unstable figures of angel and demon epiphenomena of that manifestation of Providence, the 'invisible hand' of a market that, according to Adam Smith, ultimately produces effects beneficial for the whole of society through the interest of the few? ${ }^{10}$ Is this what supersession or constant redefinition of the binary means: the reduction of angel and demon, good and evil, to figurative lability by a single market-based economic system in which we seem to have ever increasing faith?

In 1992 Francis Fukuyama delivered to us, like the angel of the Annunciation, what he called the 'good news' of the final triumph of the free market and liberal democracy. The dialectical processes of history were at an end. ${ }^{12}$ Opposition to the market, indeed, seems 
now tentative and shamefaced as if too strident a call were, if not heresy, then at least open to the accusation that, given the reality of the market's control, all positions are but market positions. Opposition thus is not opposition but simply another place within a single accommodating system. Such deep belief in the One - such monotheism - returns us to a time when resistance could only ever be superficial, when there was only one reality. It is the world of the Old Testament in which the devil did not exist except as God's agent, a faith in the superficiality of binaries that the Reformed Church was to revive. At what seems a point in history in which higher education is defined by profit and loss, how much longer may there remain those desert spaces that Hoult finds, where real alternatives might survive?

\section{Notes}

1. Norris, Christopher. 1990. What's Wrong with Postmodernism. Critical Theory and the Ends of Philosophy. Hemel Hempstead: Harvester Wheatsheaf.

2. Morrison, David. 1992. Television and the Gulf War. Ann Arbor, MI: University of Michigan Press; Taylor, Phillip M. 1992. War and the Media: Propaganda and Persuasion in the Gulf War. Manchester: Manchester University Press are both classic and detailed studies of the media coverage of the 1990-91 Gulf War. Cole, Philip. 2006. The Myth of Evil: Demonising the Enemy. Westport, CT: Greenwood Publishing Group is a more recent and general account of demonisation that brings the analysis into the twenty-first century in the last chapter ('Twenty-first Century Mythologies').

3. CBS Drama, available in the UK on Sky 149 and Freesat 135.

4. See Woolf, Virginia. 1929/1992. 'A Room of One's Own' in A Room of One's Own, Three Guineas. Ed. Moira Shiach. Oxford: Oxford University Press, 9; Woolf, Virginia. 1942. 'Professions for Women'. The Death of the Moth and Other Essays. London: The Hogarth Press, 235-38. The term was, however, already open to parody in the nineteenth century: see e.g. the cut of 'The Angel in The House; or the Result of Female Suffrage' in Punch 14 June, 1884.

5. Parker, Fred. 2011. The Devil as Muse: Blake, Byron \& the Adversary. Waco, TX: Baylor University Press.

6. Silber, Ilana F. 2009. 'Bourdieu's Gift to Gift Theory: An Unacknowledged Trajectory', Sociological Theory, 27: 173-190, 178.

7. 'Political Vampyres' 1732. The Gentleman's Magazine, 2 (May): 750-2, 751.

8. The investor won his case in 1897 , causing Jerome to sell the magazine to defray the defence costs. See Watkins, Charlotte C. 1984. 'To-day', British Literary Magazines: The Victorian and Edwardian Age 1837-1913. Ed. Alvin Sullivan. London: Greenwood Press, 416-22. 
9. Law was called the 'eldest son of Satan' in a French popular song of the time quoted in Mackay, Charles, 1841/1852/ 1995. Extraordinary Popular Delusions and the Madness of Crowds. Introduced by Norman Stone. Ware: Wordsworth, 38.

10. Smith, Adam. 1776/1976. An Enquiry into the Nature and Causes of the Wealth of Nations. Ed. R.S. Campbell, A.H. Skinner, W.B. Todd. Oxford: Oxford University Press, 456.

11. Parker 2011, 26-33.

12. Fukuyama, Francis. 1992. The End of History and the Last Man. New York: Free Press. For a parodic theological reading of Fukuyama, see Derrida, Jacques. 1994. Spectres of Marx: the State of the Debt, the Work of Mourning and the New International. Trans. Peggy Kamuf. London: Routledge, 57 et seq. 